\title{
Response of Growth and Production of Rice (Oryza sativa L) to Paclobutrazol Application with JajarLegowo 4: 1Planting System
}

\author{
Juna R. Sitepu ${ }^{1}$, Jonatan Ginting ${ }^{2 *}$, Nini Rahmawati ${ }^{2}$ \\ ${ }^{1}$ Graduate School of Agrotechnology, Department of Agricultural,Universitas Sumatera Utara \\ ${ }^{2}$ Department of Agricultural,Universitas Sumatera Utara \\ * gintingjonatan@ymail.com
}

\begin{abstract}
This study aims to evaluate the response of growth and production of three varieties of irrigated rice (Oryza sativa L.) to paclobutrazol application with jajarlegowo 4: 1planting system. This research was carried out in the rice field area of Serbajadi 1 Village, Sunggal District, Deli Serdang Regency, Medan. This study uses a separate plot design (RPT) with 2 treatment factors. The first factor is paclobutrazol as the main plot consisting of 4 levels, namely $\mathrm{P} 0=0 \mathrm{ppm}$ (without the application of paclobutrazol), $\mathrm{P} 1=50 \mathrm{ppm}, \mathrm{P} 2=100 \mathrm{ppm}$, $\mathrm{P} 3=150 \mathrm{ppm}$. The second factor is varieties as subplots consisting of 3 levels, namely, $\mathrm{V} 1=$ Inpari 32, V2 = Inpari 4, V3 = Mekongga. The results showed that the best growth and production of rice plants were in the treatment of paclobutrazol concentration of $150 \mathrm{ppm}$ in the Inpari 4 variety, with a plant height of $59.93 \mathrm{~cm}$, number of tillers 33.40 tillers, panicle number of 18.60 panicles, grain weight containing $26.98 \mathrm{~g}$ and grain production $1.82 \mathrm{~g}$ per plot.
\end{abstract}

Keywords: Oryza sativa L, varieties, paclobutrazol, jajarlegowo

\section{Introduction}

Rice is the main food crop in Indonesia because more than half of Indonesia's population makes rice a staple food. The need for rice staples continues to increase, this is not proportional to the rice production produced and consequently, the annual rice needs are not met. The low average rice production per hectare and the transfer of land-use experts are the main causes of low rice production in Indonesia [1].

In Indonesia, rice harvested area in 2015 reached 14,116 million ha, with productivity of 5,341 tons / ha, and a production of 75,397 million tons. In the province of North Sumatra, the rice harvest area in 2015 reached 781,769 ha, with the productivity of 5,174 tons/ha, and a production of 4,044 million tons [2]. In the city of Medan rice production in 2017 with a harvest area of $2,728.4$ hectares with a production of $11,994.6$ tons [3].

One of the obstacles in rice cultivation is the problem of vulnerability that causes reduced yields, early harvests and decreased grain prices. The cause of the vulnerability is the variety 
planted, including varieties that can not stand lodging. To reduce the problem of vulnerability can be done by planting superior varieties, resistant to high productivity and high yields. According to Suhartatik [4], that superior varieties are capable of high yield because plants have morphophysiological characteristics that are appropriate to their environment, that is, both planted in the lowlands and highlands.

Efforts that can be made to reduce plant height and lodging in rice are using paclobutrazol. These growth inhibitors can inhibit stem extension, increase leaf green matter, increase carbohydrate partitioning and indirectly encourage flowering without causing abnormal growth [5]

The treatment of paclobutrazol has a very significant effect on reducing plant height parameters at harvest. The results of the research [6] show that the use of paclobutrazol with a concentration of $100 \mathrm{ppm}(\mathrm{P} 2)$ tends to produce better production and a concentration of $200 \mathrm{ppm}$ (P3) tends to produce better seed quality in Ciherang variety.

Inpari 32, Inpari 4 and Mekongga varieties have a relatively long harvest period of around 116-125 days and plant height ranges from 95-115 cm [7]. In the Inpari 32, Inpari 4 and Mekongga varieties, although the plant height is classified as lower among other lowland rice, the level of lodging is classified as moderate or somewhat resistant compared to other lowland rice plants such as IR64 and other varieties. Therefore the use of paclobutrazol is expected to be able to suppress the vegetative growth of rice plants thereby diverting the use of assimilates from the need for the development of vegetative sinks to the development of reproductive sinks (seeds).

\section{Research Method}

The materials used in this study were varieties of rice seeds of Inpari 32, Inpari 4 and Mekongga and Paclobutrazol with a concentration of $250 \mathrm{~g} / 1$. This research was conducted in the rice field area of Serbajadi 1 Village, Sunggal District, Deli Serdang Regency, Medan. The study was conducted from May to August 2019. This study used a separate plot design (RPT) with 2 treatment factors. The first factor, paclobutrazol consists of 4 levels, namely, $\mathrm{P} 0=0 \mathrm{ppm}, \mathrm{P} 1=50$ ppm, $\mathrm{P} 2=100 \mathrm{ppm}, \mathrm{P} 3=150 \mathrm{ppm}$. The second factor, varieties consist of 3 levels namely, $\mathrm{V} 1=$ Inpari 32, V2 = Inpari 4, V3 = Mekongga.

Rice seedlings are planted after 12 days after seedling, using 2 rice seedlings per planting hole with a spacing of $25 \mathrm{~cm} \times 25 \mathrm{~cm}$ and a depth of $4 \mathrm{~cm}$. Rice is planted using type legowo row 1: 1 planting system with rows perpendicular to the rising sun.

Paclobutrazol was applied in each study plot by the procedure and applied when the rice plants were $30 \mathrm{HST}, 38 \mathrm{HST}$ and $46 \mathrm{HST}$. Application of Paclobutrazol 3 times by spraying all parts of the plant canopy.

Fertilization and maintenance of plants are carried out by recommendations for rice cultivation. The parameters observed were plant height $(\mathrm{cm})$, number of tillers, panicle counts, the weight of filled grain $(\mathrm{g})$ and grain production per plot $(\mathrm{kg})$. 


\section{Results and Discussion}

\subsection{Plant Height (cm)}

The results of the analysis of variance showed that the treatment of varieties and concentrations of paclobutrazol as well as the interaction of both treatments had a significant effect on the height of rice plants. The average plant height of three varieties of lowland rice due to different concentrations of paclobutrazol can be seen in Table 1.

Table 1.The average plant height of three varieties of lowland rice due to differences in the concentration of paclobutrazol at each observation time

Note: Those numbers followed by the same alphabet on the same application unreally different by Duncan test Average Difference $\alpha=5 \%$

\begin{tabular}{|c|c|c|c|c|c|}
\hline \multirow[b]{2}{*}{ DAP } & \multirow[b]{2}{*}{$\begin{array}{l}\text { Concentrations of } \\
\text { Paclobutazol }(\mathrm{P})\end{array}$} & \multicolumn{3}{|c|}{ Varieties (V) } & \multirow[b]{2}{*}{ Mean } \\
\hline & & $\begin{array}{l}\text { V1 } \\
\text { (Inpari 32) }\end{array}$ & $\begin{array}{l}\text { V2 } \\
\text { (Inpari 4) }\end{array}$ & $\begin{array}{l}\text { V3 } \\
\text { (Mekongga) }\end{array}$ & \\
\hline \multirow{6}{*}{35} & & $\ldots \ldots \ldots$ & $\ldots . . \mathrm{cm} \ldots$ & $\ldots \ldots \ldots$ & \\
\hline & P0 (0 ppm) & $61.00 \mathrm{a}$ & $56.93 \mathrm{bc}$ & $61.60 \mathrm{a}$ & $59.84 \mathrm{a}$ \\
\hline & $\mathrm{P} 1$ (50 ppm) & $61.07 \mathrm{a}$ & $55.13 \mathrm{~cd}$ & $59.13 \mathrm{ab}$ & $58.44 \mathrm{~b}$ \\
\hline & P2 (100 ppm) & $55.80 \mathrm{c}$ & $52.60 \mathrm{e}$ & $55.47 \mathrm{c}$ & $54.62 \mathrm{c}$ \\
\hline & P3 (150 ppm) & $52.87 \mathrm{de}$ & $52.47 \mathrm{e}$ & $52.40 \mathrm{e}$ & $52.58 \mathrm{~d}$ \\
\hline & Mean & $57.68 \mathrm{a}$ & $54.28 \mathrm{c}$ & $57.15 \mathrm{~b}$ & \\
\hline \multirow{5}{*}{40} & P0 (0 ppm) & $72.53 \mathrm{a}$ & $64.00 \mathrm{bc}$ & $66.67 \mathrm{~b}$ & $67.73 \mathrm{a}$ \\
\hline & P1 (50 ppm) & $65.47 \mathrm{~b}$ & 60.83 cde & $66.47 \mathrm{~b}$ & $64.26 \mathrm{~b}$ \\
\hline & P2 (100 ppm) & $61.23 \mathrm{~cd}$ & $56.40 \mathrm{f}$ & $60.87 \mathrm{cde}$ & $59.50 \mathrm{c}$ \\
\hline & P3 (150 ppm) & $56.73 \mathrm{ef}$ & $56.27 \mathrm{f}$ & $57.53 \mathrm{def}$ & $56.84 \mathrm{~d}$ \\
\hline & Mean & $63.99 \mathrm{a}$ & $59.38 \mathrm{c}$ & $62.88 \mathrm{~b}$ & \\
\hline \multirow{5}{*}{45} & P0 (0 ppm) & $80.40 \mathrm{a}$ & $71.87 \mathrm{c}$ & $76.07 \mathrm{~b}$ & $76.11 \mathrm{a}$ \\
\hline & P1 (50 ppm) & $72.20 \mathrm{c}$ & $65.80 \mathrm{de}$ & $69.47 \mathrm{~cd}$ & $69.16 \mathrm{~b}$ \\
\hline & P2 (100 ppm) & $63.53 \mathrm{ef}$ & $61.73 \mathrm{f}$ & $66.47 \mathrm{de}$ & $63.91 \mathrm{c}$ \\
\hline & P3 (150 ppm) & $63.47 \mathrm{ef}$ & $57.53 \mathrm{~g}$ & $61.13 \mathrm{fg}$ & $60.71 \mathrm{~d}$ \\
\hline & Mean & $69.90 \mathrm{a}$ & $64.23 \mathrm{c}$ & $68.28 \mathrm{~b}$ & \\
\hline \multirow{5}{*}{50} & $\mathrm{P} 0$ (0 ppm) & $87.73 \mathrm{a}$ & $80.80 \mathrm{bc}$ & $86.00 \mathrm{ab}$ & $84.84 \mathrm{a}$ \\
\hline & $\mathrm{P} 1$ (50 ppm) & $78.07 \mathrm{~cd}$ & $74.73 \mathrm{def}$ & $77.47 \mathrm{cde}$ & $76.76 \mathrm{~b}$ \\
\hline & P2 (100 ppm) & $67.40 \mathrm{gh}$ & $69.87 \mathrm{fgh}$ & $72.07 \mathrm{efg}$ & $69.78 \mathrm{c}$ \\
\hline & P3 (150 ppm) & $65.53 \mathrm{~h}$ & $59.93 \mathrm{i}$ & $66.73 \mathrm{gh}$ & $64.07 \mathrm{~d}$ \\
\hline & Mean & $74.68 \mathrm{~b}$ & $71.33 \mathrm{c}$ & $75.57 \mathrm{a}$ & \\
\hline
\end{tabular}


Data Table 1.shows that in the treatment of paclobutrazol concentration, the lowest plant height at each observation was found at the concentration of paclobutrazol $150 \mathrm{ppm}$ (P3) which was significantly different from the other treatments. At the age of 50 HST observations, there was an increase in plant height of $20.77 \mathrm{~cm}(24.56 \%)$ at a paclobutrazol concentration of $150 \mathrm{ppm}(\mathrm{P} 3)$ from plant height in the control treatment $(\mathrm{P} 0)$.

Rice varieties that produced the lowest plant height were Inpari 4 (V2), $3.35 \mathrm{~cm}$ lower than the Inpari 32 (V1) variety and $4.24 \mathrm{~cm}$ lower than the Mekongga (V3).

The treatment interaction that produced the lowest plant height was P3V2, which was 59.93 $\mathrm{cm}$ that was significantly different from other treatment interactions. Plant height in the P3V2 treatment was $27.80 \mathrm{~cm}$ lower than the P0V1 treatment $(87.73 \mathrm{~cm})$.

The results showed that plant height of three varieties of lowland rice had decreased with increasing concentrations of paclobutrazol given. Giving paclobutrazol with a concentration of $150 \mathrm{ppm}(\mathrm{P} 3)$ produced the lowest plant height of $59.93 \mathrm{~cm}$. This is because paclobutrazol is one of the growth regulators that inhibits gibberellin biosynthesis so that vegetative growth of plants is inhibited. The working principle of paclobutrazol is to inhibit the oxidation reaction between kauren and kaurenoic acid in the synthesis of gibberellins, resulting in an emphasis on plant stems)[8] Thus the plants that were given paclobutrazol were thought to have lower endogenous gibberellins compared to treatments without paclobutrazol. Gibberellin in plants, among others, plays a role in cell elongation that will determine plant height.

The variety factor has a significant influence on the height of rice plants, where the Inpari 4 variety shows a lower plant height than the Inpari 32 and Mekongga varieties. This is by the genetic makeup of each variety. Inpari 4 variety has a genetic plant height of $95-105 \mathrm{~cm}$. This is consistent with [9] that the height of the stems of plants is influenced by the traits or characteristics that affect the yield capacity of varieties. In addition to genetic factors, environmental factors and cropping systems also affect plant growth and development. In the legowo row planting system, the plant population is less than the tile system, because the planting method in the legowo row is 4: 1 , where every four rows are emptied one row of rice plants. Plant height increase in the tile system is higher than jajarlegowo. This is because the plant canopy is getting denser because of the greater plant population and the resulting quality of light received is decreased. The more population planted on land, the higher plant growth will be faster because plants are trying to find each other more sunlight [10]

\subsection{Number of Tillers}

Results of analysis of variance showed that the treatment of varieties and concentrations of paclobutrazol, as well as the interaction of the two treatments, significantly affected the number of tillers. The average number of tillers of three lowland rice varieties due to differences in paclobutrazol concentration can be seen in Table 2. 
Table 2. The average number of tillers of three rice varieties due to differences in paclobutrazol concentration at each observation time

Note: Those numbers followed by the same alphabet on the same application unreally different by Duncan test Average Difference $\alpha=5 \%$

\begin{tabular}{|c|c|c|c|c|c|}
\hline \multirow[b]{2}{*}{ DAP } & \multirow[b]{2}{*}{$\begin{array}{l}\text { Concentrations of } \\
\text { Paclobutazol (P) }\end{array}$} & \multicolumn{3}{|c|}{ Varieties (V) } & \multirow[b]{2}{*}{ Mean } \\
\hline & & $\begin{array}{c}\text { V1 } \\
\text { (Inpari 32) }\end{array}$ & $\begin{array}{c}\text { V2 } \\
\text { (Inpari 4) }\end{array}$ & $\begin{array}{c}\text { V3 } \\
\text { (Mekongga) }\end{array}$ & \\
\hline \multirow{5}{*}{35} & & & ..tiller.. & & \\
\hline & P0 (0 ppm) & $22.27 \mathrm{~cd}$ & $23.60 \mathrm{bcd}$ & $22.60 \mathrm{~cd}$ & $22.82 \mathrm{c}$ \\
\hline & P1 (50 ppm) & $22.20 \mathrm{~d}$ & $23.33 \mathrm{bcd}$ & $25.53 \mathrm{a}$ & $23.69 \mathrm{~b}$ \\
\hline & P2 (100 ppm) & $22.67 \mathrm{~cd}$ & $25.73 \mathrm{a}$ & $22.80 \mathrm{~cd}$ & $23.73 \mathrm{~b}$ \\
\hline & P3 (150 ppm) & $24.07 \mathrm{abc}$ & $25.40 \mathrm{a}$ & $24.60 \mathrm{ab}$ & $24.69 \mathrm{a}$ \\
\hline & Mean & $22.80 \mathrm{c}$ & $24.52 \mathrm{a}$ & $23.88 \mathrm{~b}$ & \\
\hline \multirow{5}{*}{40} & P0 (0 ppm) & $24.20 \mathrm{~d}$ & $24.87 \mathrm{~cd}$ & $24.13 \mathrm{~d}$ & $24.40 \mathrm{c}$ \\
\hline & P1 (50 ppm) & $25.13 \mathrm{bcd}$ & $25.87 \mathrm{abc}$ & $26.20 \mathrm{abc}$ & $25.73 \mathrm{~b}$ \\
\hline & P2 (100 ppm) & $23.80 \mathrm{~d}$ & $26.87 \mathrm{a}$ & $26.93 \mathrm{a}$ & $25.87 \mathrm{~b}$ \\
\hline & P3 (150 ppm) & $25.80 \mathrm{abc}$ & $26.53 \mathrm{ab}$ & $26.67 \mathrm{ab}$ & $26.33 \mathrm{a}$ \\
\hline & Mean & $24.73 \mathrm{c}$ & $26.03 \mathrm{a}$ & $25.98 \mathrm{~b}$ & \\
\hline \multirow{5}{*}{45} & P0 (0 ppm) & $25.47 \mathrm{~d}$ & $29.00 \mathrm{a}$ & $27.00 \mathrm{bcd}$ & $27.16 \mathrm{c}$ \\
\hline & P1 (50 ppm) & $26.53 \mathrm{~cd}$ & $27.53 \mathrm{abc}$ & $27.60 \mathrm{abc}$ & $27.22 \mathrm{c}$ \\
\hline & P2 (100 ppm) & $26.27 \mathrm{~cd}$ & $28.80 \mathrm{a}$ & $28.53 \mathrm{ab}$ & $27.87 \mathrm{~b}$ \\
\hline & P3 (150 ppm) & $28.73 \mathrm{a}$ & $28.40 \mathrm{ab}$ & $28.47 \mathrm{ab}$ & $28.53 \mathrm{a}$ \\
\hline & Mean & $26.75 \mathrm{c}$ & $28.43 \mathrm{a}$ & $27.90 \mathrm{~b}$ & \\
\hline \multirow{5}{*}{50} & P0 (0 ppm) & $28.93 \mathrm{c}$ & $30.93 \mathrm{~b}$ & $29.67 b c$ & $29.84 \mathrm{c}$ \\
\hline & P1 (50 ppm) & $30.47 b c$ & $30.73 b c$ & $29.60 b c$ & $30.27 \mathrm{~b}$ \\
\hline & P2 (100 ppm) & $30.40 \mathrm{bc}$ & $30.93 \mathrm{~b}$ & $30.53 b c$ & $30.62 \mathrm{~b}$ \\
\hline & $\mathrm{P} 3(150 \mathrm{ppm})$ & $30.27 \mathrm{bc}$ & $33.40 \mathrm{a}$ & $32.73 \mathrm{a}$ & $32.13 \mathrm{a}$ \\
\hline & Mean & $30.02 \mathrm{c}$ & $31.50 \mathrm{a}$ & $30.63 \mathrm{~b}$ & \\
\hline
\end{tabular}

Data from Table 2. shows that in the treatment of paclobutrazol concentration, the highest number of tillers in each observation was at the concentration of paclobutrazol $150 \mathrm{ppm}$ (P3) which was significantly different from the other treatments. At the age of 50 HST observations, there was an increase in the number of tillers $2.4(7.4 \%)$ at a paclobutrazol concentration of 150 ppm (P3) from plant height in the control treatment (P0).

Rice varieties that produced the highest number of tillers were Inpari 4 (V2), namely 31.50 tillers that were significantly different from Mekongga (V3), which were 30.63 tillers and Inpari 32 (V1), namely 30.02 tillers.

The treatment interaction that produced the highest number of tillers was P3V2, ie 33.40 tillers that were significantly different from other treatment interactions. The number of tillers in the P3V2 treatment was 4.47 more than the P0V1 treatment (28.93 tillers).

The number of tillers increased with increasing concentrations of paclobutrazol given. Wattimena [5] added that one of the physiological effects of retardant is that it encourages bud formation. Apart from the application of paclobutrazol, the increase in the number of tillers is also influenced by the planting system used. The results of this study are [11] stating the treatment distance of 4: 1 legowo row planting has a number of productive tillers (14.43) that is significantly 
different from other planting distances namely legowo row 2: 1 and 3: 1 in Inpari 13 variety rice. [12] also states that the legowo 4: 1 table system provides productive tillers per clump higher than the legowo 2: 1table system, namely 29 each (27-32 tillers), far higher than compared to productive tillers based on varieties 14-17 tillers).

The variety factor shows a significant effect on the number of tillers, where the number of tillers differs in each variety. The highest number of tillers was in Inpari 4 and the lowest was in Inpari 32. This proves that genetics is the main factor influencing the number of tillers produced. According [11] the number of tillers will be maximal if the plant has good genetic traits coupled with favorable environmental conditions or by plant growth and development. In addition to genetic, factor 4: 1 jajarlegowo planting system supports the formation of a total number of tillers. This is due to the lower plant population thereby reducing competition in nutrient absorption and sunlight, this is [11] opinion that the maximum number of tillers is also determined by plant populations because plant populations determine the absorption of solar radiation, mineral nutrients and crop cultivation itself. Plant populations that have less competition for sunlight and nutrients are very few compared to many plant populations.

\subsection{Number of panicles}

The results of the analysis of variance showed that the treatment of varieties and concentrations of paclobutrazol, as well as the interaction of the two treatments, significantly influenced the number of panicles per rice plant. The average number of panicles per plant of three rice varieties due to differences in the concentration of paclobutrazol can be seen in Table 3 .

Table 3. The average number of panicles of three rice varieties due to differences in the concentration of paclobutrazol

Note: Those numbers followed by the same alphabet on the same application unreally different by Duncan test Average Difference $\alpha=5 \%$

\begin{tabular}{lcccc}
\hline \multirow{2}{*}{$\begin{array}{c}\text { Concentration of } \\
\text { Paclobutrazol } \\
(P)\end{array}$} & \begin{tabular}{c} 
V1 \\
\cline { 2 - 4 }
\end{tabular} & $\begin{array}{c}\text { V2 } \\
\text { (Inpari 32) }\end{array}$ & $\begin{array}{c}\text { V3 } \\
\text { (Mekongga) }\end{array}$ & Mean \\
\hline & $\ldots \ldots \ldots$. & ..panicle.. & $\ldots \ldots \ldots$ & \\
P0 (0 ppm) & $15.47 \mathrm{e}$ & $16.80 \mathrm{~d}$ & $15.53 \mathrm{e}$ & $15.93 \mathrm{~d}$ \\
P1 (50 ppm) & $15.87 \mathrm{e}$ & $16.73 \mathrm{~d}$ & $16.67 \mathrm{~d}$ & $16.42 \mathrm{c}$ \\
P2 $(100 \mathrm{ppm})$ & $17.60 \mathrm{bc}$ & $17.93 \mathrm{abc}$ & $17.33 \mathrm{~cd}$ & $17.62 \mathrm{~b}$ \\
P3 $(150 \mathrm{ppm})$ & $18.20 \mathrm{ab}$ & $18.60 \mathrm{a}$ & $18.47 \mathrm{a}$ & $18.42 \mathrm{a}$ \\
\hline Mean & $16.78 \mathrm{c}$ & $17.52 \mathrm{a}$ & $17.00 \mathrm{~b}$ & \\
\hline
\end{tabular}

Data Table 3 shows that in the treatment of paclobutrazol concentration, the highest number of panicles per plant was found in the concentration of paclobutrazol $150 \mathrm{ppm}$ (P3) which was significantly different from other treatments. The number of panicles per plant experienced an increase of 2.49 panicles $(13.51 \%)$ at a paclobutrazol concentration of $150 \mathrm{ppm}$ (P3) from the number of panicles per plant in the control treatment $(\mathrm{P} 0)$.

Rice varieties that produced the highest number of panicles per plant were Inpari 4 (V2), 17.52 panicles, which were significantly different from Mekongga (V3), which were 17.00 panicles and Inpari 32 (V1), 16.78 panicles. 
The treatment interactions that produced the highest number of panicles per plant were P3V2, ie 18.60 panicles that were significantly different from other treatment interactions. The number of panicles per plant in the P3V2 treatment was 3.13 panicles more than the P0V1 treatment (15.47 panicles).

The results showed that the number of panicle parameters per plant increased with increasing concentrations of paclobutrazol given. This shows that the role of paclobutrazol is very significant in inhibiting growth. According to [13] inhibition of rice is caused by paclobutrazol which can block the synthesis of gibberellins, which are growth-regulating compounds that function in plant cell elongation. Inhibition of the production of gibberellins does not inhibit cell division, but the new cells produced do not grow lengthwise [14].

\subsection{Grain Weight Contains (g)}

The results of the analysis of variance showed that the treatment of varieties and concentrations of paclobutrazol, as well as the interaction of the two treatments, significantly affected the weight of unhusked rice per clump of rice. The average weight of grains contained per clump of three rice varieties due to differences in concentrations of paclobutrazol can be seen in Table 4.

Table 4. The average grain weight containing three rice varieties due to different concentrations of paclobutrazol

Note: Those numbers followed by the same alphabet on the same application unreally different by Duncan test Average Difference $\alpha=5 \%$

\begin{tabular}{lcccc}
\hline \multirow{2}{*}{$\begin{array}{c}\text { Concentrations of } \\
\text { Paclobutrazol } \\
(\mathrm{P})\end{array}$} & \begin{tabular}{c} 
V1 \\
\cline { 2 - 4 }
\end{tabular} & $\begin{array}{c}\text { V2 } \\
\text { (Inpari 32) }\end{array}$ & $\begin{array}{c}\text { V3 } \\
\text { (Inpari 4) }\end{array}$ & Mean \\
\hline & $\ldots \ldots \ldots \ldots$ & $\ldots$. gram... & $\ldots \ldots \ldots$ & \\
P0 (0 ppm) & $24.74 \mathrm{abcd}$ & $24.26 \mathrm{bcd}$ & $23.22 \mathrm{~d}$ & $24.08 \mathrm{~b}$ \\
P1 (50 ppm) & $24.14 \mathrm{bcd}$ & $26.23 \mathrm{ab}$ & $23.32 \mathrm{~cd}$ & $24.56 \mathrm{~b}$ \\
P2 (100 ppm) & $23.27 \mathrm{~cd}$ & $25.51 \mathrm{abc}$ & $26.63 \mathrm{a}$ & $25.14 \mathrm{a}$ \\
P3 (150 ppm) & $25.88 \mathrm{ab}$ & $26.98 \mathrm{a}$ & $24.92 \mathrm{abcd}$ & $25.93 \mathrm{a}$ \\
\hline Mean & $24.51 \mathrm{~b}$ & $25.75 \mathrm{a}$ & $24.52 \mathrm{~b}$ & \\
\hline
\end{tabular}

Data Table 4 shows that the treatment of paclobutrazol concentration of $150 \mathrm{ppm}(\mathrm{P} 3)$ resulted in the heaviest weight of grain contained per heaviest clump of 25.93 grams that was significantly different from other treatments. The weight of unhulled rice per clump at the treatment of paclobutrazol concentration is $150 \mathrm{ppm}(\mathrm{P} 3)$ heavier 1.85 grams than the weight of the filled grain per clump at the control treatment $(\mathrm{P} 0)$.

Rice varieties that produce grain weight per heaviest clump are Inpari 4 (V2) that is 12.07 grams that is significantly different from Inpari 32 (V1) that is 10.79 grams and Mekongga (V3), which is 11.55 grams.

The treatment interaction that produced the heaviest weight of grains per heaviest clump was P3V2, which was 26.98 grams that were significantly different from other treatment interactions. The weight of filled grain per clump in the P3V2 treatment was 3.76 grams heavier than the P0V3 treatment (23.22 grams). 
Paclobutrazol is a retardant that can shorten the stem of the plant, so the plant will become stronger. Besides the ability to shorten plant stems, these growth inhibitors can increase leaf chlorophyll content. Increased chlorophyll content will increase the ability of plant leaves to carry out the process of photosynthesis that produces carbohydrates. This increase in carbohydrate production will increase the grain yield of rice plants [15]. This is consistent with the results of the study that the weight of paddy containing rice was higher with the application of paclobutrazol compared to without the application of paclobutrazol.

The variety factor gives a significantly different effect on the weight of filled grains per clump. This is by the potential yield of each variety. According to Abdullah et al (2008), if the amount of grain per clump is large, the cooking period will be longer, so that the quality of rice will decrease or the level of emptiness is high, due to the inability of the source to fill in the sink.

\subsection{Grain production / plot (g)}

Results of analysis of variance showed that the treatment of varieties and concentrations of paclobutrazol as well as the interaction of the two treatments had a significant effect on grain production per rice plot. The average grain production per plot of three rice varieties due to differences in paclobutrazol concentration can be seen in Table 5 .

Table 5. The average grain production per plot of three rice varieties due to differences in the concentration of paclobutrazol

Note: Those numbers followed by the same alphabet on the same application unreally different by Duncan test Average Difference $\alpha=5 \%$

\begin{tabular}{ccccc}
\hline \multirow{2}{*}{$\begin{array}{c}\text { Concentration of } \\
\text { Paclobutrazol } \\
(\mathrm{P})\end{array}$} & $\begin{array}{c}\mathrm{C} 1 \\
\text { (Inpari 32) }\end{array}$ & $\begin{array}{c}\text { V2 } \\
\text { (Inpari 4) }\end{array}$ & $\begin{array}{c}\text { V3 } \\
\text { (Mekongga) }\end{array}$ & Mean \\
\hline P0 (0 ppm) & $\ldots \ldots \ldots$ & $\ldots . \mathrm{kg} \ldots$ & $\ldots \ldots \ldots$ & \\
P1 (50 ppm) & $1.20 \mathrm{fg}$ & $1.30 \mathrm{defg}$ & $1.38 \mathrm{cdefg}$ & $1.29 \mathrm{~d}$ \\
P2 (100 ppm) & $1.25 \mathrm{fg}$ & $1.57 \mathrm{abcde}$ & $1.28 \mathrm{efg}$ & $1.37 \mathrm{c}$ \\
P3 (150 ppm) & $1.12 \mathrm{~g}$ & $1.70 \mathrm{ab}$ & $1.45 \mathrm{bcdef}$ & $1.42 \mathrm{~b}$ \\
Mean & $1.63 \mathrm{abc}$ & $1.82 \mathrm{a}$ & $1.60 \mathrm{abcd}$ & $1.68 \mathrm{a}$ \\
\hline
\end{tabular}

Data Table 5 shows that the treatment of $150 \mathrm{ppm}$ (P3) paclobutrazol concentration resulted in the heaviest grain production per plot which was $1.68 \mathrm{~kg}$ which was significantly different from the other treatments. Grain production per plot in the treatment of $150 \mathrm{ppm}(\mathrm{P} 3)$ paclobutrazol concentration heavier $0.39 \mathrm{~kg}$ than grain production per plot in the control treatment (P0).

Rice varieties that produce grain production per heaviest plot are Inpari 4 (V2), which is 1.60 $\mathrm{kg}$, which is significantly different from Inpari 32 (V1), which is $1.30 \mathrm{~kg}$ and Mekongga (V3), which is $1.43 \mathrm{~kg}$.

The treatment interaction that produced the heaviest grain production per plot was P3V2, which is $1.82 \mathrm{~kg}$ that was significantly different from other treatment interactions. Grain production per plot in the P3V2 treatment was $0.7 \mathrm{~kg}$ heavier than the P2V1 treatment $(1.12 \mathrm{~kg})$.

The results showed that the variety factor significantly affected the production of rice grain produced, where the Inpari 4 variety had the highest grain yield potential compared to the other 
two varieties. This is due to the genetic factors of the plant itself. According to [16]states that the most important factor to obtain the highest grain yield is the number of productive tillers and the number of panicles formed. The more productive saplings that produce panicles, the more grain is produced.

\section{Conclusion}

The concentration of paclobutrazol that gives the best effect on growth and production is 150 $\mathrm{ppm}$. The rice varieties that have the best growth and production are Inpari 4 . The interaction of paclobutrazol treatment and the varieties that produce the best growth and production is the concentration of $150 \mathrm{ppm}$ paclobutrazol in the Inpari 4.

\section{References}

[1] Nurwita, E.S. Pertumbuhan dan Produksi Padi Yang Ditanam Dengan Metode System Of Rice Intensification (SRI) Di Desa Limo, Depok, Jawa Barat. Skripsi. Institut Pertanian Bogor. Bogor (2009).

[2] BPS. Luas panen, produktivitas, dan produksi tanaman padi provinsi Indonesia. [diacu 2017 Juni]. Tersedia dari: http://www.bps.go.id. (2017).

[3] BPS Provinsi Sumatera Utara Provinsi Sumatera Utara dalam Angka 2018. Badan Pusat Statistik Provinsi Sumatera Utara. Produksi Padi dan Palawija Sumatera Utara. (2018)

[4] Suhartatik, E dan A.K. Makarim. Morfologi dan Fisiologi Tanaman Padi. Balai Besar Penelitian Tanaman Padi. Bogor (2008).

[5] Wattimena, G. A. Zat Pengatur Tumbuh Tanaman. Lab. Jaringan Tanaman. PAU Bioteknologi IPB. Bogor (1988).

[6] Riani, N dan R. Dwi. Aplikasi Paclobutrazol dan Pupuk Makro Anorganik Terhadap Hasil dan Mutu Benih Padi (Oryza sativa L.). Journal of Applied Agricultural Sciences. Jember. Vol. 1, No.1, Hal. 22-34. (2017.

[7] Bambang. S.,H Purwaningsih. : Kajian keragaan varietas unggul baru padi sawah dengan pengelolaan tanaman terpadu di Bantul Yogyakarta. Jurnal Pengkajian dan Perkembangan Teknologi (2014).

[8] Salisbury, F. B. dan C. W. Ross. Fisiologi Tumbuhan Jilid 3. ITB Bandung. Bandung. (1995)

[9] Suprihatno, B: Deskripsi Varietas Padi. Balai Besar Penelitian Tanaman Padi. Badan Penelitian dan Pengembangan Pertanian Kementerian Pertanian Sukamandi, Jawa Barat. (2010). 
[10] Nursanti, R. Pengaruh Umur Bibit dan Jarak Tanam Terhadap Pertumbuhan dan Produktivitas Tanaman Buru Hotong (Setariaitalica (L.) Beauv). Skripsi Program Studi Agronomi. Fakultas Pertanian. Institut Pertanian Bogor. Hal 27-28 (2009).

[11] Harun, R., N.Pomalingo., F. Zakaria. Sistem Tanam Jajar Legowo dengan Kombinasi Dosis Pupuk Phonskadan Urea Terhadap Pertumbuhan dan Hasil Tanaman Padi Sawah (Oryza sativa L.) varitas Inpari 13.Seminar Hasil Penelitian. Universitas Negeri Gorontalo (2012).

[12] Sirappa, M. P.: .Kajian Perbaikan Teknologi Budidaya Padi Melalui Penggunaan Varietas Unggul dan Sistem Tanam Jajar Legowo Dalam Meningkatkan Produktivitas Padi Mendukung Swasembada Pangan. Jurnal Budidaya Pertanian 7: 70-86 (2011).

[13] Rademacher, WGrowth Retardants: Effects on Gibberellins Biosynthesis and Other Metabolic Pathways. Annual Review Plant Physiology Plant Molecular Biology 51:501-531 (2000).

[14] Sinniah, U. R., S. Wahyuni, B. S. A. Syahputra, and S. Gantait. :. A Potential Retardant for Lodging Resistance in Direct Seeded Rice (Oryza sativa L.). Can. J. Plan Sci. 92:13- 18. DOI:10.4141/CJPS2011-089 (2012).

[15] Runtunuwu, S.D., D.M.F. Sumampouw., P. Tumewu., R. Mamarimbing., R.M.N. Rengkung. Respon Paklobutrazol terhadap Pertumbuhan dan Hasil Padi Lokal Wesel. Eugenia 22(3). (2016).

[16] Arraudeau. M.A dan B.S. Vergara. Pedoman Budidaya Padi Gogo. BPTP. Sukarami (1992). 